\title{
GEOPHYSICS OF A DOLINE SHAFT SYSTEM
}

\section{Peter J. Hutchinson}

THG Geophysics, Ltd., 4280 Old Wm. Penn Hwy., Murrysville, Pennsylvania, 15668 USA, pjh@thggeophysics.com

\author{
Alex Balog \\ THG Geophysics, Ltd., 4280 Old Wm. Penn Hwy., Murrysville, Pennsylvania, 15668 USA, axb@thggeophysics.com
}

\section{Danica R. Pils}

California University of Pennsylvania, 250 University Ave., California,PA15419 USA,pil9785@calu.edu

\begin{abstract}
Memorial Athletic Field, State College, Pennsylvania was installed within an existing doline shaft system. Although its early history included such uses as waste disposal and limestone mining, the Works Project Administration in the late 1930s converted the doline into Memorial Stadium. Subsequently, a surface opening (throat) on the north side of the field was connected to a series of pipes that drain 20 hectares of street runoff. A major issue with exploiting the throat for runoff disposal is that the void beneath grew over time due to erosion, dissolution, and subsidence.
\end{abstract}

The top of rock within the athletic field is roughly funnel-shaped and the interior of the "funnel" contains periglacial sediments as imaged through electrical imaging (EI) and microgravity (MG) mapping. Profiles of the EI data using a forward modeling program show a well-developed void beneath the bleachers. The microgravity data also show the presence of a north-south deep-rooted fracture system that probably opens to a larger series of voids at depths of greater than 20 meters.

\section{Introduction}

Memorial Athletic Field, a high school football field located in State College, Pennsylvania, has served many purposes since State College was incorporated in 1896 (Figure 1). Through much of the 19th century and the beginning of the 20th century, the Memorial Field depression was used for waste disposal, and referred to as "The Hollow" (Smith, 2011). Penn State University purchased the sinkhole land in 1914 with plans to develop the area as a recreation space for a new elementary school located on Nittany Avenue.

Eventually, the Chamber of Commerce saw the land's potential and had Penn State's Architecture Department design plans for a campus extension that included a sports stadium. There was no real progress with the project until 1935, when a program under the New Deal funded the project with approximately $\$ 100,000$ (Smith, 2011). The Works Progress Administration program included mining limestone with most of the stone quarried to be used for the development of the field that included building retaining walls and the southern bleachers (Figure 2). Quarrying, apparently, was not a separate commercial endeavor.

The first sporting event was held October 1, 1937. In 1946, the stadium was renamed Memorial Field in honor of the high school students from State College who gave their lives in World Wars I and II.

At some point, following the development of the field, a throat on the north side of the field that connected to a deep-seated void was subsequently exploited for street drainage. A series of storm water pipes were connected from adjoining streets and provided street drainage via the throat (Figure 3). The throat, located beneath the bleachers on the north side of the field, has shown steady subsidence in the decades since street runoff of some 20 hectares was routed to the sinkhole. A major issue with years of storm water discharge to the throat is that the throat widened and the void beneath grew due to erosion, dissolution, and subsidence.

Geophysical methods, microgravity and electrical imaging, were determined to be the most expedient and least expensive method to image the void beneath the sinking bleachers and the athletic field.

\section{Geology}

Memorial Field is developed into the karst-forming dolomitic Axeman Formation, a part of the Ordovicianaged Beekmantown Group (Figure 4). The Beekmantown is over 2,000 meters $(\mathrm{m})$ thick in the area study area (Thompson, 1999). Memorial Stadium is located on 


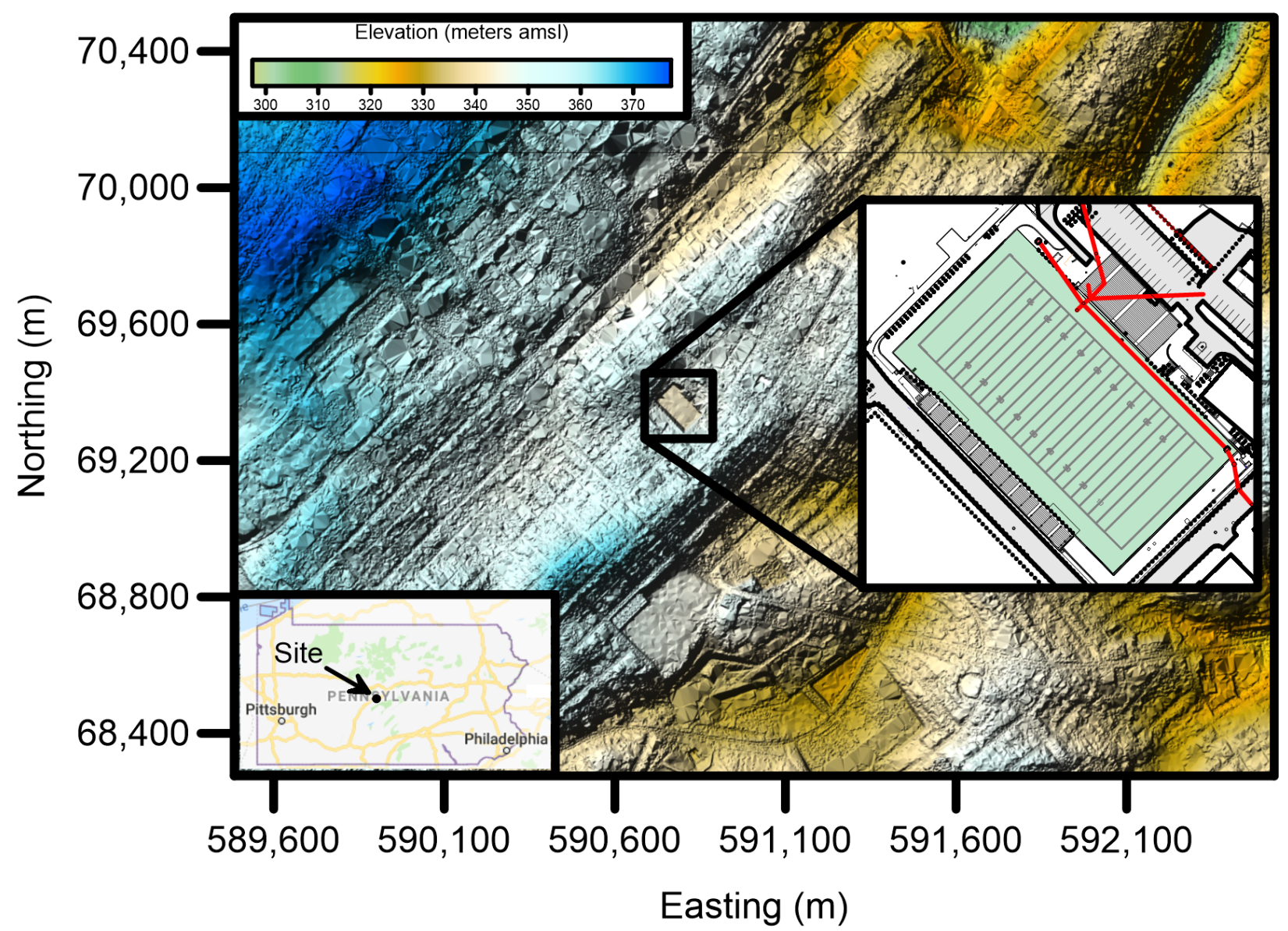

Figure 1. Digital elevation model (1 m grid; North American Vertical Data 1988, 2006-2008 Department of Conservation and Natural Resources PAMAP) of Memorial Athletic Field in State College, Pennsylvania. Upper right inset map shows existing storm drains at Memorial Athletic Field (in red).

the northwestern side of the northeast plunging Nittany Syncline (Clarke, 1965).

Several of karst features, consisting of dolines, voids and shafts, within the State College area have been identified and geophysically-mapped (e.g., Hutchinson and Vidarsson, 2006; Hutchinson et al., 2020). Many of the dolines are circular and tens of meters in diameter but show only minor surface depression, on the order of a few meters. Unfortunately, surface expression in the form of subsidence usually occurs after surface disturbance or from construction; consequently, if left undisturbed these features do not seem to readily enlarge or collapse (Hutchinson et al., 2020).

\section{Geophysical Methods}

The geophysical investigation into the extent and nature of the doline shaft system of Memorial Stadium consisted of EI and MG mapping. EI and MG profiles

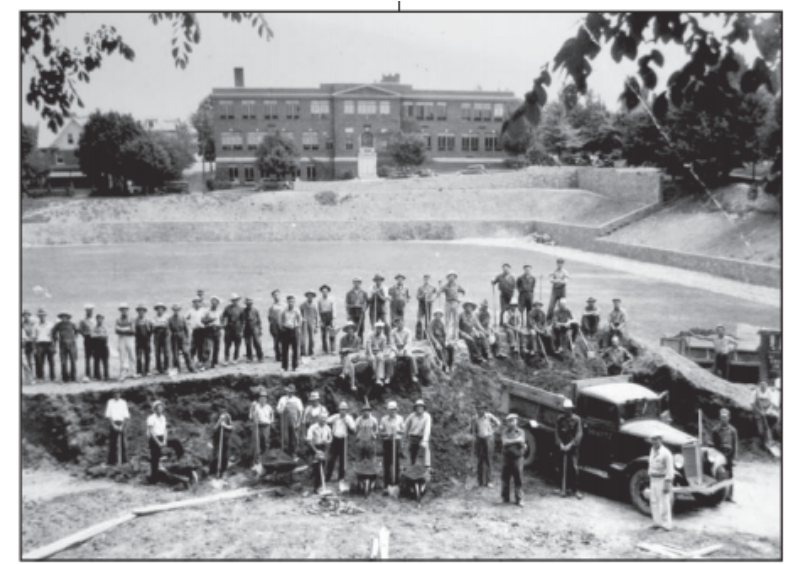

Figure 2. Works Project Administration workers during the construction of Memorial Field, circa 1937. View of the stadium to the south (from Smith, 2011). 

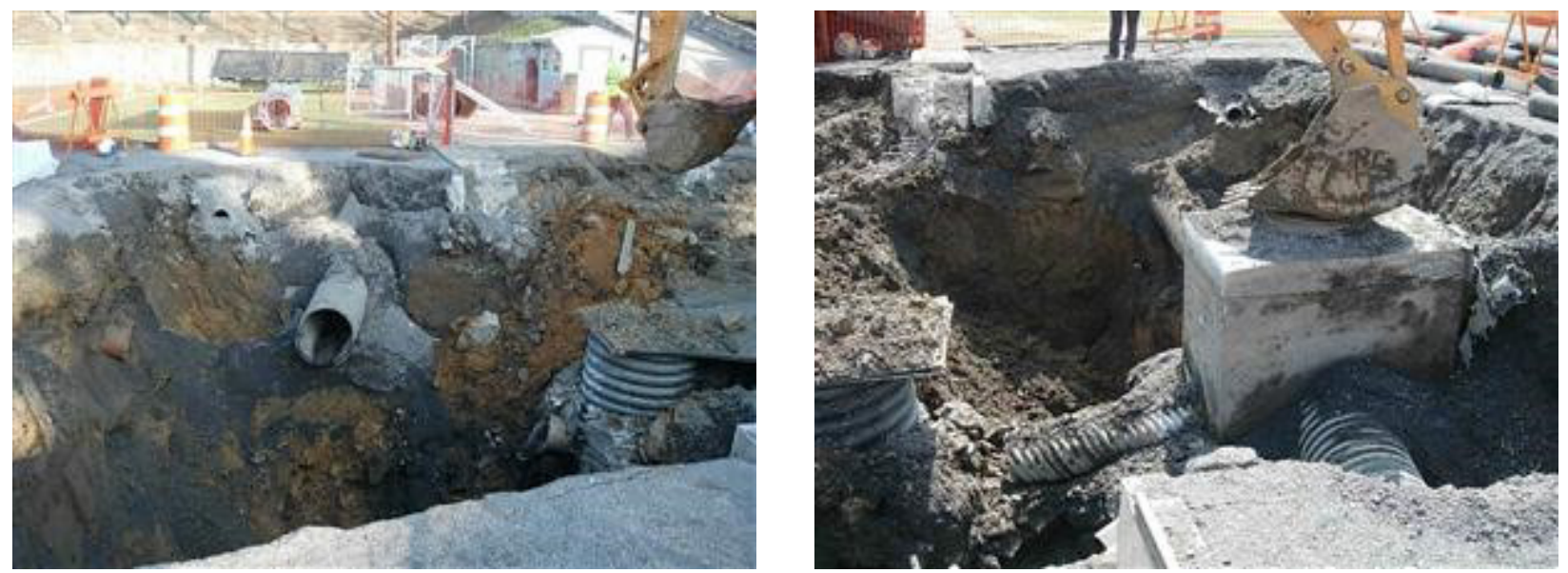

Figure 3. Excavation of the subsiding reinforced concrete manhole in April 2013. Note the 0.5 meter diameter pipes feeding the manhole.

were collected parallel to the established football field grid. Collection occurred every 3 meters for the EI profiles and microgravity soundings were collected every 1.5 meters along the "10-yard" chalk-marked lines.

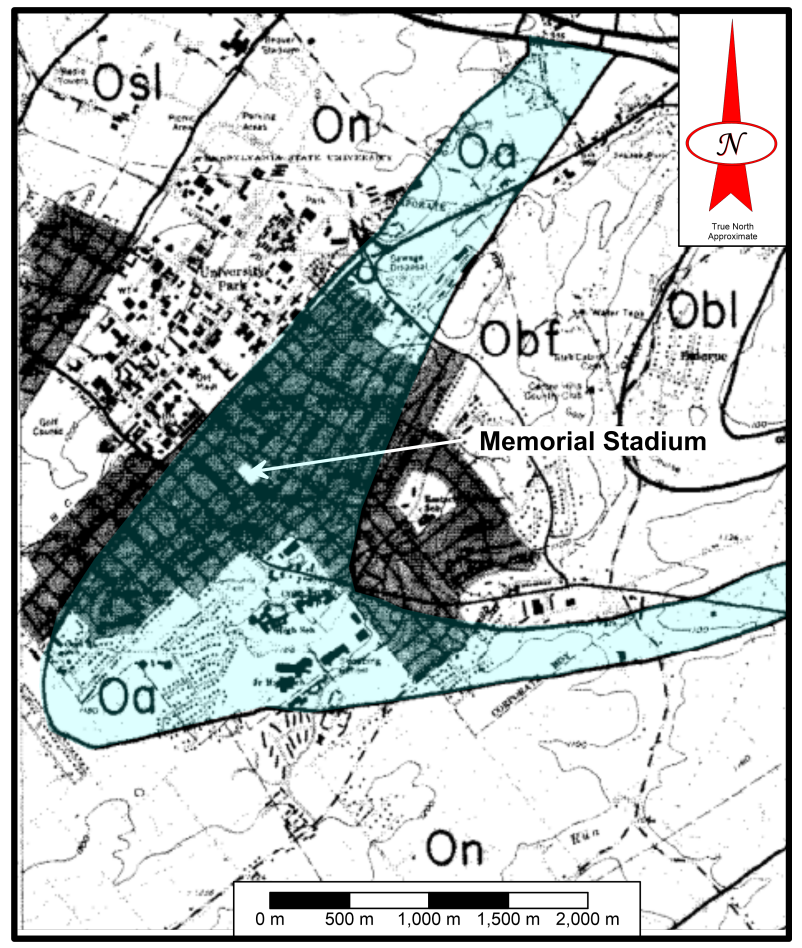

Figure 4. A portion of the State College, Pennsylvania geologic 1:24,000 quadrangle map. Geologic units include the Ordovician Stonehenge/Larke (Osl); Nittany Formation (On); Axeman Formation (Oa); Bellefonte Formation (Obf); and Benner Formation to Loysburg Formation (Obl) (Berg and Dodge, 1981).

\section{Electrical Imaging}

Electrical resistance is based upon Ohm's Law; where, resistance is equal to the ratio of potential to current flow. Resistivity, then, is a measure of the resistance along a linear distance of a material with a known crosssectional area. Consequently, resistivity is measured in Ohm-meters and data can be presented as geo-electrical profiles or tomographs that represent a geoelectrical response to subsurface conditions.

Electrical currents propagate as a function of three material properties (1) ohmic conductivity, (2) electrolytic conductivity, and (3) dielectric conductivity. Ohmic conductivity is a property exhibited by metals (Kaufman, 1992). Electrolytic conductivity is a function of the concentration of total dissolved solids and salts in the groundwater that exists in the pore spaces of a material (Reynolds, 2011).

Therefore, the matrix of most soil and bedrock is highly resistive. Of these three properties, electrolytic conductivity is the dominant material characteristic that influences the apparent resistivity values collected by this method (Milsom, 1989).

In general, resistivity values decrease in water-bearing rocks and soil with increasing: fractional volume of the rock occupied by groundwater; total dissolved solid and chloride content of the groundwater; permeability of the pore spaces; and, temperature.

Materials with minimal primary pore space (i.e., limestone, dolomite) will exhibit high resistivity values (Mooney, 1980). Highly porous, moist or saturated soil, such as fat clays, will exhibit very low resistivity values. 
In homogeneous ground, the apparent resistivity is the true ground resistivity; however, in heterogeneous ground, the apparent resistivity represents a weighted average of all formations through which the current passes (Mooney, 1980). Data was collected using GF Instruments ARES II continuous ground resistivity meter. Each profile was collected using a Schlumberger array with 3 m electrode spacing.

A forward modeling subroutine was used to calculate the apparent resistivity values using the EarthImager program (AGI, 2002). This program is based on the smoothness-constrained least-squares method (deGroot-Hedlin and Constable, 1990; Loke and Barker, 1996).

The EarthImager program divides the subsurface 2-D space into a number of rectangular blocks. Resistivities of each block are then calculated to produce an apparent resistivity pseudosection. The pseudosection is compared to the actual measurements for consistency. A measure of the difference is given by the root-meansquared (rms) error.

The processed readings were converted to a color that represents solid rock (>300 Ohm-m; dark blue-red hues), saturated fractured rock (35 to $300 \mathrm{Ohm}-\mathrm{m}$; green hues), and saturated voids (<35 Ohm-m; light blue hues). Subsurface voids are interpreted as clay-filled and/or fully saturated, thus have a very low apparent resistivity; whereas, the dolomite/limestone has a very high apparent resistivity. Unfortunately, it is difficult to separate water-filled voids from clay-filled voids with electrical imaging methods.

\section{Microgravity}

MG measurements are not readily impacted by cultural noise; consequently, MG measurements can be col- lected in buildings and adjacent to urban development (Milsom, 1989). Microgravity has been used for many geologic purposes; however, for the environmental geophysicist, microgravity is used to determine the presence of subsurface voids, to image subsurface bedrock topography, and to find the depth of waste (Carmichael and George, 1977; Kick, 1985; Stewart, 1980).

Small changes in rock density produce small changes in the gravity field that can be measured by the MG (Hinze, 1990). These readings change from day to day due to tidal response and lunar pull, among other phenomena that have an impact on the earth's gravitational flux.

MG measures the acceleration due to the earth's gravitational field (in $\mathrm{mGal}=0.001 \mathrm{~cm} / \mathrm{sec}^{2}$ ) using an astatic spring mechanism (Carmichael and George, 1977). Gravity is calculated in units of acceleration, thus the CGS (centimeter, gram, second) system units for gravity, mGal, has been replaced by the SI unit for the pull of gravity, g.u. (1 g.u. $=1 \mathrm{vm} / \mathrm{s}^{2}$; and 1 g.u. $\left.=0.1 \mathrm{mGal}\right)$. Processing raw gravity data includes corrections for latitude, elevation, Bouguer gravity, tidal, and terrain.

Latitude corrections were automatically corrected by the MG meter by subtracting the International Gravity Formula normal datum from the observed gravity. The elevation or free-air correction normalizes the gravity data to a given datum that does not have to be sea level. Bouguer corrections account for the rock mass between the measuring station and sea level which is related to density and known thickness above sea level.

\section{Geophysical Investigation Electrical Imaging}

The EI profiles show the top of the carbonate rock beneath the field to be funnel-shaped with the interior of

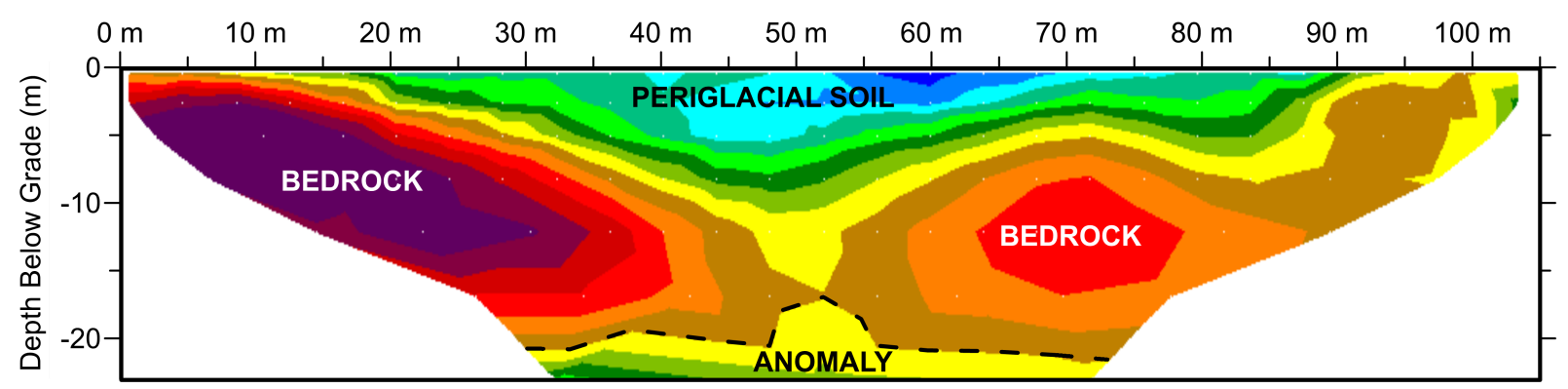

Figure 5. An example of an inverted geoelectric profile along the eastern "50-yard" line of Memorial Athletic Stadium showing the funnel-shape to the sinkhole. See text for color scale; map scale as shown with no vertical exaggeration. 
the "funnel" filled with periglacial clay (Figure 5). This interpretation did not show the potential for collapse or subsidence. Structurally, though, clay tends to migrate towards the center or deepest part of the "funnel" over time; however, this phenomenon is not quantifiable but has been recorded in other areas of State College (Hutchinson, et al, 2020). Some subsidence was noticed on the southern side near the southern bleachers suggesting that basinward migration is occurring.

The historical and recent subsidence beneath the northern bleachers triggered this investigation of the throat that receives storm water discharge. The void below the throat is rimmed with an inferred 1.5 meter cap or roof of carbonate rock (Figure 6). The void is estimated to be 12 meters by 15 meters in size in plan view. The base of the void beneath the throat is $>6$ meters below surface at its deepest part and is almost invariably clay-filled.

\section{Microgravity}

A plan map using gravity data created with a forward modeling program also shows a well-developed clayfilled sinkhole beneath the bleachers (Figure 7). In the southwest-northeast orientation, the deepest portion of the sinkhole beneath the bleachers is estimated to be 4 meters wide; whereas in the northwest-southeast direction the sinkhole is estimated to be 10 meters wide.

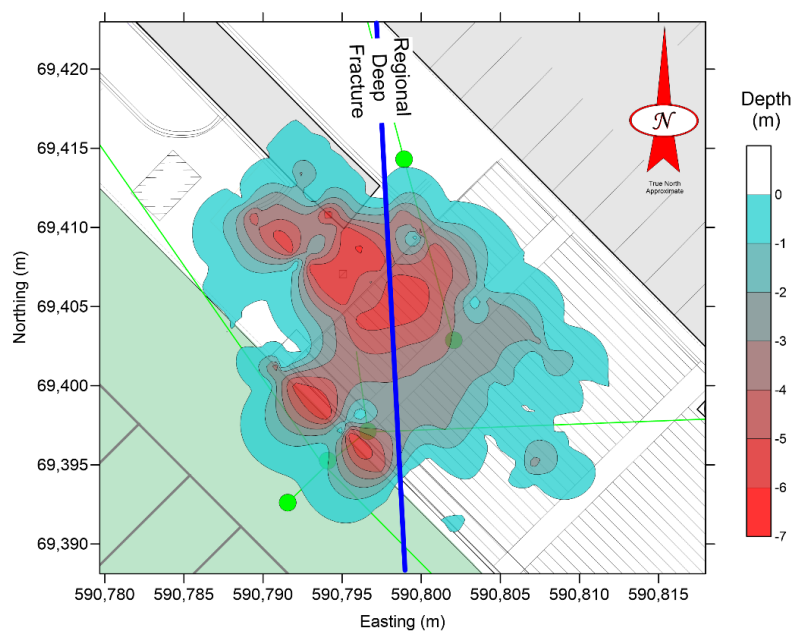

Figure 6. Plan map of the sinkhole area beneath the northern bleachers at Memorial Stadium. Depth to top of rock map based upon El profile interpretation. Note location of interpreted regional fracture (blve). Plan map based upon North American Datum 83 Pennsylvania North State Plane (m).
Forward modeling of the gravity data shows that the top of rock is 6 meters below grade consistent with the EI profiles. The forward model is based upon limited gravity data (i.e., sounding or point collection); consequently, the gravity model did not quite meet the exact footprint of the interpretation from the EI profiles.

Structurally, the top of the void has supported the stands for many years. The long-term use of the void as a discharge point for storm water runoff; however, has eroded the deeper cavern and possibly thinned the roof of the feature thus causing the subsidence of the bleachers.

The MG investigation within the athletic field of Memorial Stadium was pivotal in determining areas of potential hazards. A plan map of the depth to rock from forwardmodeled MG data shows that the top of the limestone is funnel-shaped (Figure 8). The forward model used to create this map was based upon the specific gravity of clay which is much lower than that of limestone/dolomite (Figure 9).

The top of rock map generated from forward modeling of gravity profile data within the athletic field shows a well-developed periglacial clay-filled sinkhole (Fig-

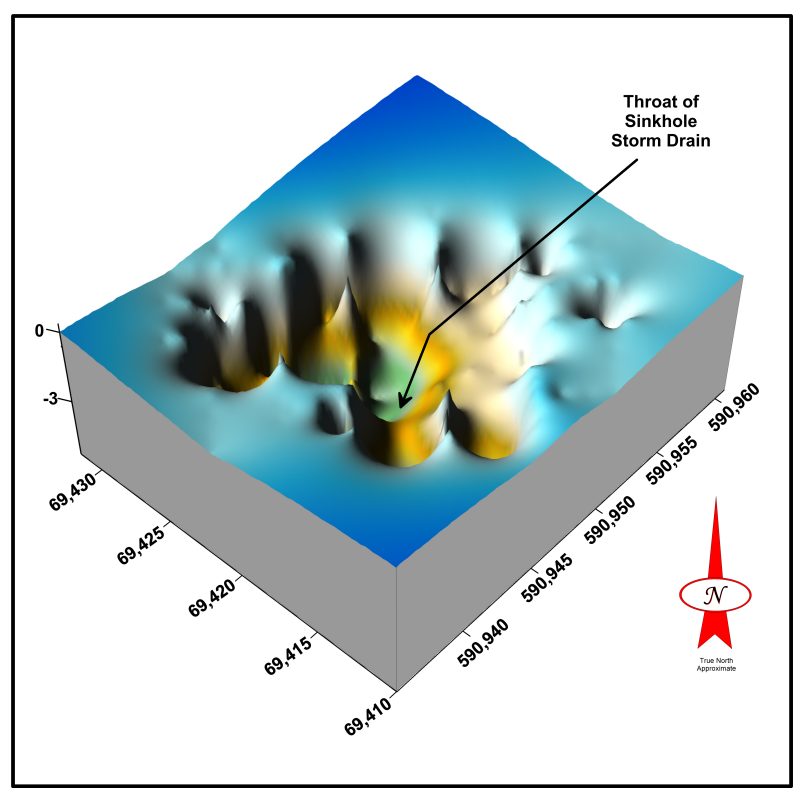

Figure 7. A 3-D representation of the corrected microgravity data showing the void beneath the northern bleachers. The color contours represent depth to the top of carbonate rock beneath the bleachers. Plan map based upon North American Datum 83 Pennsylvania North State Plane (m). 
ure 8). The microgravity data also shows the regional fracture (area between blue lines) that accounts for the surficial karst features in this area (Figure 8).

Further, the deep-rooted fracture that is inferred to run nearly north-south can be documented by: (1) the surface subsidence noted near the copse of trees by the northern access driveway; (2) the location of the throat of the void; (3) the deepest portion of the doline in roughly the center of the athletic field; and, (4) the subsidence noted along S. Fraser Street (Figure 8).
This fracture system probably opens to a larger series of voids at depths of greater than 20 meters (Figure 5). A doline shaft system model most appropriately describes the athletic field's relationship to karst development (Figure 10).

\section{Conclusion}

A sub-regional south-north oriented fracture system is inferred to cut through the center of Memorial Athletic Stadium. A doline exists along the fracture trace that is centrally located within the stadium. The doline, now

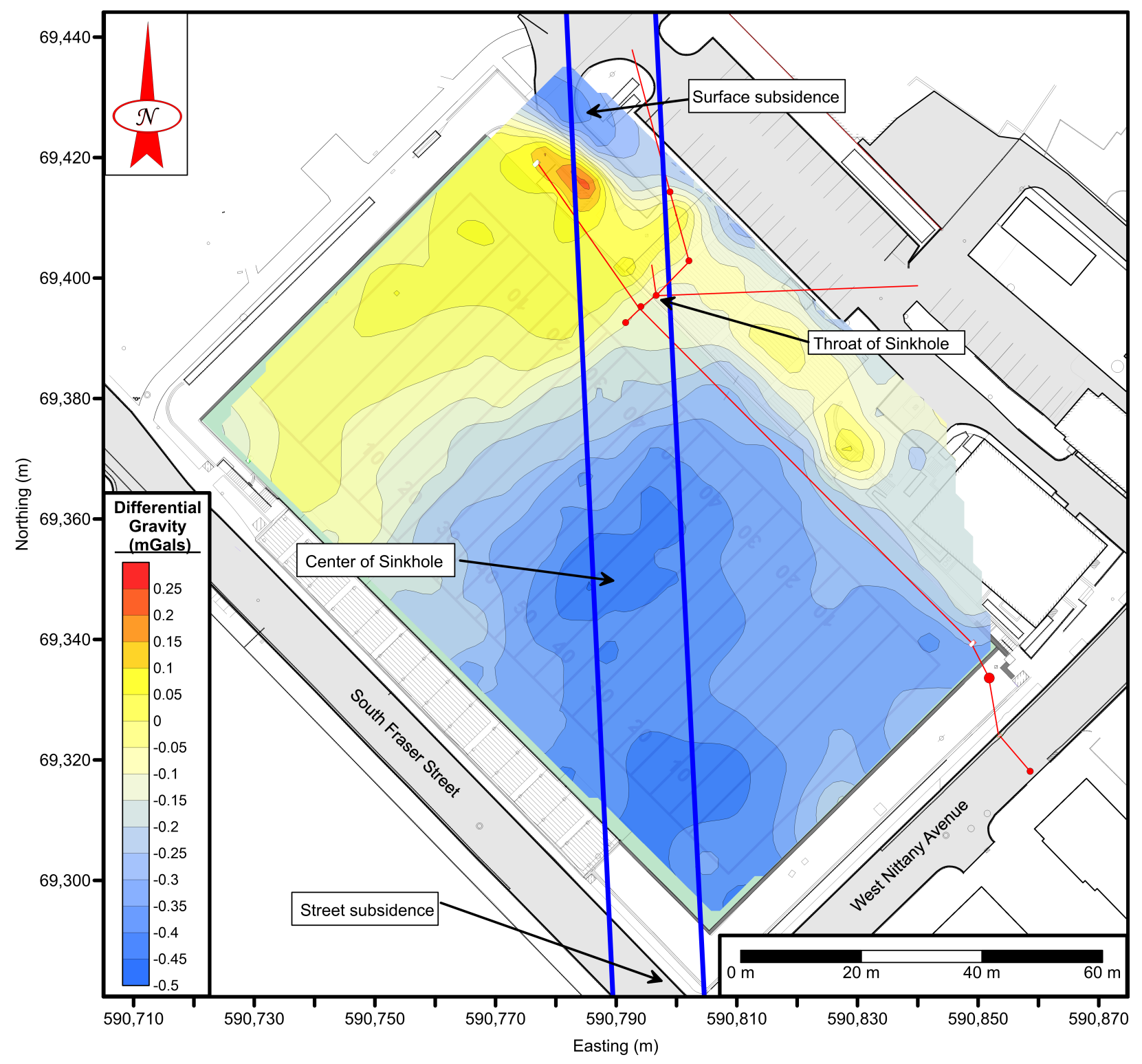

Figure 8. Top of rock map based upon the differential gravity and superimposed on Memorial Stadium. Coordinate system North American Datum 83 Pennsylvania North State Plane (m). Area between the blue lines represents the regional fracture system. 


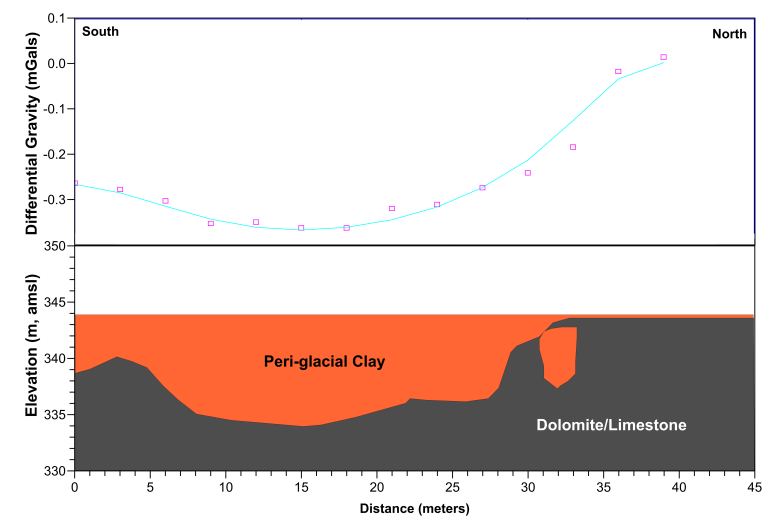

Figure 9. Forward-modeled profile of the sinkhole beneath the "35 Yard" line in Memorial Stadium. Vertical exaggeration 1.5 times.

represented by an athletic field, is filled to grade with periglacial clay.

A surface hole or throat to a void located beneath the northern bleachers to Memorial Stadium is situated along the alignment of the sub-regional fracture system. The throat is in communication with the subregional system, probably through a system of well-developed caverns and enlarged, interconnected fractures. In plan view, the shallow void beneath the bleachers is approximately 12 meters by 15 meters. This void, used for storm water disposal, is no deeper than 2 meters below grade at its deepest point but is in full communication with a deeper subregional fracture/cavern system (i.e., greater than $6 \mathrm{~m})$.

The throat is currently a discharge point for the City of State College's storm sewer for approximately 20 hectares that surround the stadium (Figure 1). The historical use of the throat for storm water disposal has weakened the rock supporting the roof of the void causing subsidence in the area around the inlet to the throat. This subsidence will likely continue as the void grows from erosion and dissolution caused by the continued use for storm water disposal.

The differential gravity map provides a sub-regional view of the extent of doline development within the athletic field and that Memorial Field is a well-developed clay-plugged doline.

\section{References}

AGI. 2002. EarthImager Program. American Geosciences Inc., Austin Texas.

Berg TM, Dodge CM. 1981. Atlas of Preliminary Geologic Quadrangle Maps of Pennsylvania, Pennsylvania Geological Survey, Harrisburg, Map $61,636 \mathrm{p}$.

Carmichael RS, Henry G. 1977. Gravity Exploration for Groundwater and Bedrock Topography in

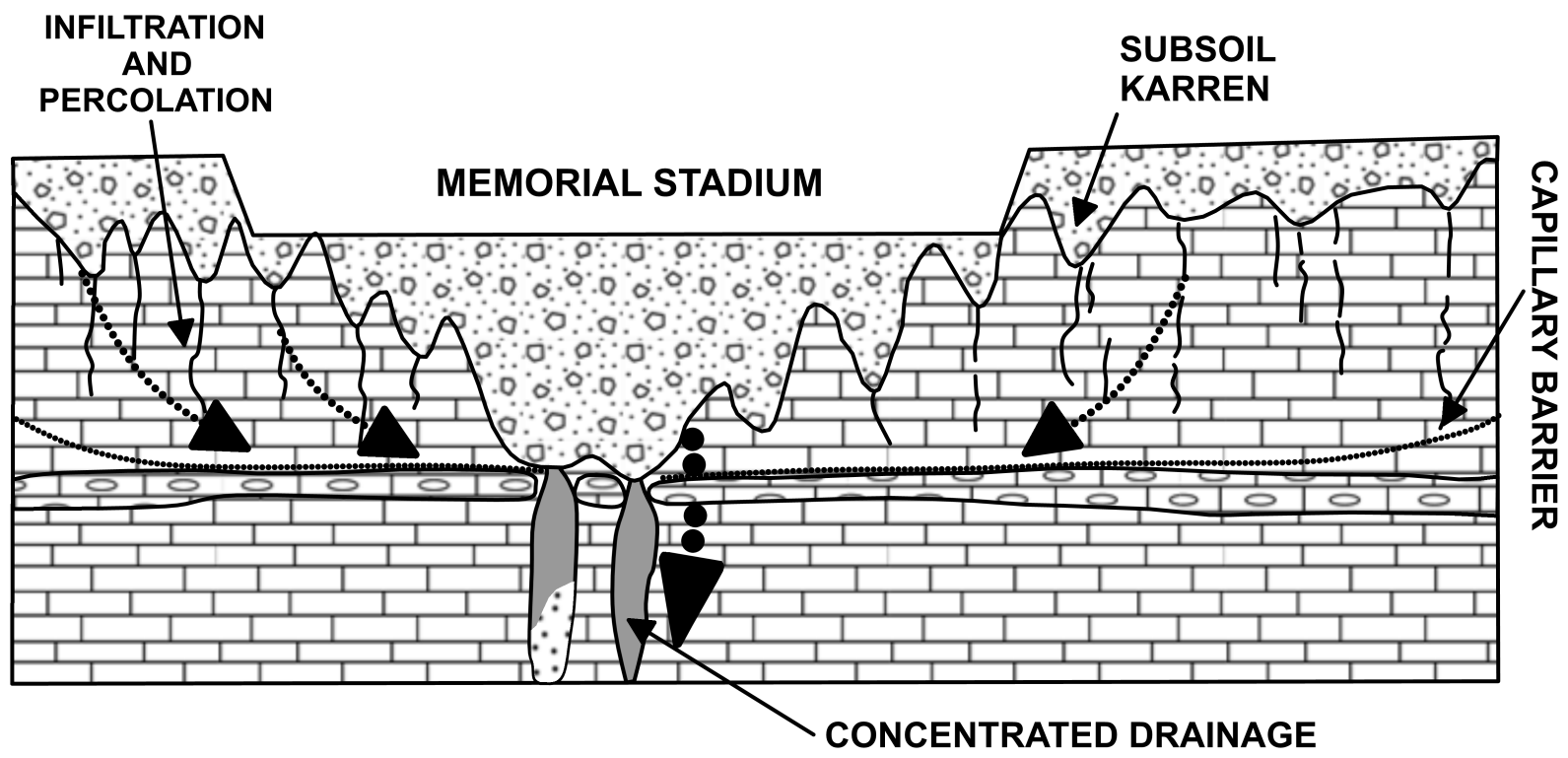

Figure 10. A south-north profile of Memorial Stadium showing its relationship to the doline shaft system (modified from Sauro, 2012). Figure is not to scale. 
Glaciated Areas: Geophysics, v. 42, no. 4, p. 850-859.

Clarke JH. 1965. The geology of the Ordovician carbonate formations in the State College, Pennsylvania, area and their relationship to the general occurrence and movement of groundwater. Unpublished Master's Thesis. The Pennsylvania State University, State College, Pennsylvania. 114 p.

deGroot-Hedlin C, Constable S. 1990. Occam's inversion to generate smooth, two-dimensional models from magnetotelluric data. Geophysics, V. 55, 1613-1624.

Hinze WJ. 1990. 4. The Role of Gravity and Magnetic Methods in Engineering and Environmental Studies (Ward SH, Ed.): Geotechnical and Environmental Geophysics, p. 75-126.

Hutchinson PJ, Balog A, Hoover SE. 2020. Microgravity mapping of an inception doline shaft system. Environmental and Engineering Geoscience. In press; V25(5). p. 1-9.

Hutchinson PJ, Vidarsson AM. 2006. Case Studies of Mine Voids Using Continuous Vertical Electrical Sounding Methods. In: Proceedings of the International Conference on Environmental and Engineering Geophysics, June 4-6, 2006, Wuhan, China; pp 270-280.

Kaufman AA. 1992. Geophysical field theory and method: Part A, gravitational, electric, and magnetic fields: Academic Press. 581 p.

Kick JF. 1985. Depth to bedrock using gravimetry: The Leading Edge, v. 4, no. 4, p. 38-42.

Loke MN, Barker RD. 1996. Rapid least-squares inversion of apparent resistivity pseudosection by quasi-Newton method. Geophysical Prospecting, v. $44,131-152$.

Milsom J. 1989. Field Geophysics: Open University Press, New York, New York. 182 p.

Mooney HM. 1980. Handbook of Engineering Geophysics: Volume 2: Electrical Resistivity: Bison Instruments, Inc., Minneapolis, Minnesota.
Reynolds JM. 2011. An introduction to applied and environmental geophysics: Wiley-Blackwell. 796 p.

Sauro U. 2012. Closed Depressions in Karst Areas, in Culver DC, White WB eds., Encyclopedia of Caves, Academic Press, Amsterdam. p. 140-155.

Smith RA. 2011. Origin and Construction of State College's "Sinkhole" Memorial Field. Mansion Notes, v. 33, No. 3. 1 p.

Stewart MT. 1980, Gravity Survey of a Deep Buried Valley: Ground Water, v. 18, no. 1, p. 24-30.

Thompson AM. 1999. Ordovician, in Shultz CH, ed., The geology of Pennsylvania: Pennsylvania Geological Survey and Pittsburgh Geological Society Special Publication 1. p. 75-89. 